\title{
Researches on the Innovation of Model Intangible Asset Management
}

\author{
Pengwu Wang ${ }^{1}$ \\ ${ }^{1}$ School of Accounting,Harbin University of Commerce;Harbin,China;150028
}

Keywords: Intangible assets; Accounting management; Contents, Organization; Tools; System; Innovation

\begin{abstract}
: the management of intangible assets is becoming more and more important in enterprise management, however,there exist many problems in management of intangible assets in our country at present and the traditional management models are no longer suitable for the management of intangible assets in the new period that there appears an urgent call for the innovation of intangible assets management models. Based on the author's years of practical experience, this paper first analyzes current problems existing in the management of intangible assets in enterprises, and then establishes innovation system of intangible assets in enterprises from contents, organization, tools and system.
\end{abstract}

\section{Introduction}

It is pointed out in the Chinese Enterprise Accounting Standards that intangible assets refer to identifiable non-monetary assets which have no physical form owned or controlled by enterprises and the traditional intangible assets include patents, trademark rights, copyrights, franchises and other rights. Based on the four aspects as accounting confirmation, measurement, records and reports, intangible asset management models in the new periods mainly include concept, measurement, amortization, information disclosure and other contents. With the intensification of market economy and the advent of the era of knowledge economy, high technology, brand image and human capital development and other projects of the enterprises have become essential components of intangible assets and core competitive factors.

\section{The Main Problems Existing in the Management of Intangible Assets of Enterprises}

Narrow contents of intangible assets management. The traditional view proposes that intangible assets include patents, non patented technologies, trademarks, copyrights, the right of land use etc. Enterprises have payed more attention to above-mentioned aspects in the management of intangible assets, however, in the era of knowledge economy, the contents of intangible assets have expanded more that brand management, enterprise strategy, human resources management have become parts of intangible assets which can not be ignored in the management of intangible assets. Therefore, it is really significant for the managers of enterprises to change their mind and re-examine the object of intangible assets management.

Backward concepts in intangible assets management. It is prevalent phenomenon in most enterprises that they will emphasize tangible assets rather than intangible assets and for some enterprises, even though they also attach importance to management of intangible assets, they can not reach what they have expected due to the deviation in management philosophy. Managers often split the management of tangible assets and intangible assets apart, when they mentioned about 
tangible assets, intangible assets will not be considered, and tangible assets will not be taken into consideration when talking about intangible assets, ignoring the connection between intangible assets and tangible assets. Actually, management for intangible assets will contribute to increasing value of tangible assets, which will improve the whole value of the enterprise, and management for tangible assets will provide basic conditions for intangible asset management.

Monotonous methods in intangible assets management. If intangible assets are only confined to the financial statements of the enterprise, it's impossible to acquire complete information of intangible assets, not alone managing well the intangible assets of the enterprise. However, distortion of intangible assets information is a realistic problem, which has resulted to severe loss of intangible assets. A number of enterprises have neglected information collection, tracking, summary and feedback of intangible assets, resulting in the the lack of complete and specific record and information, making the financial statements rootless and intractable. Therefore, it is essential to innovate management methods of intangible assets, making information reflected more transparent.

Lack of management system of intangible assets. To strengthen the management of intangible assets, related system must be constructed, while as a matter of fact in enterprise management, there exist many loopholes in the intangible asset management. Firstly, many enterprises lack of specialized personnel and institutions on the intangible assets management and will only transfer personnel from other departments temporarily when necessary, which will surely lead to lower level in specialization of intangible assets management; What's more, they often lack of detailed investment budget and feasibility analysis in the cultivation and development stage of intangible assets and they haven't taken input costs and expected benefits into consideration practically so that excessive profit can not be obtained; Last but not least, enterprises often ignore the maintenance of intangible assets that intellectual property rights violations have occurred more often than not.

\section{Establishment of the Enterprise Intangible Assets Management Innovation System}

Innovation in contents of intangible assets management. First of all, the explicit intangible assets management and implicit intangible assets management shall be combined. Enterprises have more comprehensive and profound understanding for traditional intangible assets, such as patent rights, trademark rights and proprietary technologies. Compared with these traditional rights, there exist some implicit intangible assets which will easily be ignored by enterprises, such as knowledge resources, enterprise strategies, enterprise cultures and other assets, which also play significant roles in enterprise management and shall be applied in the contents of management of intangible assets. What's more, human resource management and knowledge resource management shall be combined. The subject of intangible asset management is staff in enterprises and knowledge resource is essential for staff in enterprises so that to enhance management of intangible asset management, human resource and knowledge resource, as the very beginning of everything, must be highlighted. On one hand, enterprises shall give material or spiritual rewards to employees to encourage innovation and stimulate their enthusiasm for innovation so that employees will be maintained by making them realizing their own value. On the other hand, staff of the enterprises will become closer to each other and have mutual trust to each other through the establishment of employee communication platform, realizing the internal knowledge and information resources sharing within the enterprise.

Organization innovation of the intangible assets management. First of all, the team for intangible assets management shall be established. Intangible assets management requires specialized personnel and institutions and enterprises shall set up a specialized management team 
focusing on operation, maintenance, and performance evaluation. Mutual communication shall be ensured between staff and departments of the enterprise to reach information sharing. Secondly, the management mechanism of innovation for intangible assets and human resources shall be constructed. To start with, human resource environment shall be cultivated. Management for intangible assets of the enterprise is closely related to its human resource environment since no matter senior managers of the enterprise or general staff should attach great importance to the development, operation and maintenance of intangible assets, which shall be presented in managing philosophy, service means and methods. Philosophy for intangible assets management shall be taken into consideration in the strategic planning of human resources, the introduction of talents, compensation design, performance management and so on, to fully mobilize employees enthusiasm to participate in the management of intangible assets in enterprises, maximize their creativity and gradually realize the integration of intangible asset management and human resource management. Secondly,human resource assessment mechanism shall be established. Assessment for staff of enterprises shall not follow the traditional method of ranking by seniority, instead, related intangible assets factors shall be considered, formulating related human resource assessment index to intangible capital and evaluate performance of the employees through both quantitative and qualitative aspects.

Tools innovation for intangible assets management. Firstly, the information system of intangible assets shall be established. At present,management means for intangible assets in our country are relatively backward and related information of intangible assets can only be presented through the accounting tables which have significant limitations. Therefore,information system of intangible assets shall be established to record and track intangible assets management information of enterprises comprehensively and systematically to provide strong basis for decision-making management authorities. Static information database and dynamic database shall be established in accordance with the needs of the enterprise and related historical data and information of intangible assets management shall be reflected in the static information database, as the deposit and log file, to provide a reference for the future work of the intangible asset management. Let's take the trademarks and patents as examples, the domestic and international registration and application for trademarks and patents will be clear through information management so objection or void can be proposed timely to reduce conflict of rights, in particular, to prevent the occurrence of malicious cybersquatting and maintain intangible assets of enterprises.

Secondly, the intangible assets information system shall be included in the enterprise information system. Intangible assets information system shall not be independent from enterprise information system, but become a most significant part of the enterprise information system. At present, accounting of most of the enterprises has been completed by financial software design that accounting computerization has almost been realized. At the same time, the informationization management of intangible assets can provide additional information for accounting electric calculation as well as present information of intangible assets in the reports more comprehensively and truly. Therefore, the enterprise should promote the scientific and standardized management of intangible asset information to make a full use of system information of intangible assets in the information construction of enterprises and business management.

System innovation for intangible assets management. First of all, system of intangible asset development shall be established. To begin with, a clear development goal and investment direction shall be confirmed. Research and development of intangible assets are committed to enhancing the self-development capability of enterprises, establishing the core competitiveness and emphasizing their own brands. Enterprises shall develop the core technology purposely which has market values 
and could adapt to the diversified development of the enterprise when investing or innovate based on the technology introduced to form independent intellectual property rights. Secondly, research and development budget and the allocation of funds shall be performed well. Enterprises should expect future costs for research and development reasonably to determine the extent of the capital budget quota and control within the range when applied in specific situation to avoid excessive cost.The allocation of funds shall be performed in accordance with the standard and arbitrary appropriation shall be avoided. Last but not least, feasibility analysis in research and development and the evaluation of the investment project shall be performed. Enterprises can make decision according to the net present value method on research and development programme, which means that only when net present value is greater than zero that the programme will be considered as feasible.

Secondly, operation strategy of intangible assets shall be innovated. The operation of intangible assets refers that the enterprise realizes the maximum of profit through unified planning, co-ordination arrangements to all kinds of intangible assets of the enterprise. Enterprises should innovate operation strategy of intangible assets to deepen the operation of intangible assets.

Thirdly, maintenance system of intangible assets shall be improved. Enterprises must enhance the consciousness of protecting intangible assets positively and specialized management agencies shall be set up to be responsible for intangible assets of different characteristics. For the intangible assets on rights, such as patent right, trademark right, copyright etc, enterprises should complete the application process after the development of these intangible asset projects timely and sought legal protection as soon as possible. For the violation of the rights of the enterprise and occupation of intangible assets, enterprises shall respond timely and make full use of laws to safeguard their legitimate rights and interests. For the other intangible assets than rights, for example, proprietary technologies owned by the enterprise should be protected by reasonable internal control. Related technical personnel shall sign a confidentiality agreement with enterprise and incentive and restraint mechanisms shall be established to prevent the loss of intangible assets.

Finally, performance evaluation system of intangible assets shall be established. Intangible assets evaluation is very significant to evaluate the managers' performance and reflect the management level of intangible assets and the enterprise should take the financial and non-financial indicators into consideration to construct performance evaluation system of intangible assets. Financial indicators include reflection index of the intangible assets operating ability, index of intangible assets profitability and reflection value-added index. And the enterprises should also take the influence of non-financial indicators into consideration, for example, cycle length of intangible assets development, market shares of product brand and increase, decrease or other change of customer lists etc.

\section{Conclusion}

With the deepening of the market economy and the arrival of the era of knowledge economy, the contents of intangible assets of the enterprise have become more abundant and been an important factor in determining the core competitiveness of enterprises. As for the accounting management of the intangible assets,the contents, organization, tools and system of intangible assets must be innovated in order to better adapt to the pace of global economic integration and improve the efficiency of accounting management of intangible assets, ultimately enhancing the core competitiveness of enterprises.

\section{References}


[1] Wenjuan Zhao. Reflections on Improvement of High-tech Enterprises Intangible Assets Accounting $[\mathrm{J}]$. Journal of Shenzhen University (Human Social Sciences Edition),2007,01:76-80.

[2] Min Zhang.The Road to Great Enterprises-- Analysis on Effective Management of Intangible Assets and Improvement of Enterprise Core Competitiveness[J]. Heilongjiang International Business and Economics,2008,10:87-89.

[3] Yu Meng. Reflection on the Problem of Intangible Assets Accounting Under the Era of Knowledge Economy[J]. Journal of Nanjing University of Finances and Economics, 2014,02:74-76+82.

[4] Qiang Yu, Study on the Intangible Assets of the Service Outsourcing Enterprises [J]. Friends of Accounting(Journal for Later Month),2010,02:30-31. 